\title{
Evaluation of Three Peach Cultivars (Prunus persica L.) Grown in Egypt under North Delta Conditions
}

\author{
M. A. Zayan, S. M. Zeerban, G. B. Mikhael ${ }^{*}$ and H. M. \\ Abo Ogiela* \\ Pomology Department, Faculty of Agriculture, Kafrelsheikh \\ University, Kafrelsheikh and ${ }^{*}$ Deciduous FruitTree Department, \\ Horticulture Research Institute, Agricultural Research Centre, \\ Cairo, Egypt.
}

\begin{abstract}
THIS investigation was carried out during 2007 and 2008 seasons on eight years old peach trees grown in a commercial orchard located at Sedy Salem District, Kafrelsheikh governorate, Egypt. to evaluate and compare vegetative growth, flowering bud fertility, maturity, yield and fruit quality of three peach cultivars namely, Florida Prince, Early Grand and Desert Red under North Delta condition. The evaluation of the three peach cultivars exhibited that "Desert Red" cultivar produced highest yield, but its fruit reach maturity later in the third week of May. However, "Early Grand" cultivar obtained least number of fruits per tree with intermediate yield $(\mathrm{kg})$ per tree and highest fruit quality particularly fruit weight, size TSS and anthocyanin content, but its fruit maturity occurred at early May. Furthermore, "Florida Prince" cultivar started vegetative and flower buds very early, and produced highest significant number of flower buds, most of them born on the basal part of the shoot and recorded the longest shoot and internode. It recorded the highest fertility index. Therefore, produced highest number of fruits per tree with low quality. In addition, this cultivar reached full bloom early on the end of January and fruit maturity occurred by early of April and thus is considered early harvest cultivar .
\end{abstract}

Keywords: Peach cultivars, Evaluation, Vegetative growth, Yield, Fruit characteristics.

Peach is one of the most important deciduous fruit trees grown in Egypt. The total planted area increased rapidly through the last three decades due to introduced several peach cultivars of low and moderate chilling requirements by the Agricultural Development system (Stine et al., 1982, Mansour \& Stino, 1986a \& 1986b and Shaltout, 1987). It reached about 80609 feddans with a production of about 273256 tons according to the last statistics of Ministry of Agriculture and Land Reclamation (2010). There are very few information about the different characteristics of these newly introduced peach cultivars viz. behavior of bud opening, vegetative growth, flowering, yield and fruit quality(Mohamed, 1995). Accordingly, this study was planned to evaluate the performance of three peach genotypes, namely Florida Prince, Early Grand and Desert Red under North Delta conditions and comparing their bud fertility. 


\section{Materials and Methods}

The present study was carried out during tow successive seasons of 2007and 2008 on eight years old Florida Prince, Early Grand and Desert Red peach cvs. trees (Prunus persica L. Batsch) budded on Nemaguard rootstock, spaced at $4 \times 4$ $\mathrm{m}$, trained to an open-vase system and grown in private orchard located at Sedy Salem district, Kafrelsheikh Governorate. Trees were subjected to horticulture practices usually done in this region. The depth of water table is about 140-160 $\mathrm{cm}$. The orchard soil is classified as clay and slightly alkaline. Other chemical and physical properties of the experimental soil are presented in Table 1.

TABLE 1. Some chemical and physical properties of the experimental soil.

\begin{tabular}{|c|c|c|c|}
\hline \multirow[t]{2}{*}{ Soil variable } & \multicolumn{3}{|c|}{ Soil depth $(\mathrm{cm})$} \\
\hline & 0-30 & $30-60$ & $60-90$ \\
\hline $\mathrm{pH}$ & 8.20 & 8.20 & 7.90 \\
\hline $\mathrm{EC} \mathrm{mmhos} / \mathrm{cm}$ & 2.29 & 1.78 & 1.75 \\
\hline $\mathrm{SAR}^{*}$ & 4.78 & 3.97 & 3.91 \\
\hline OM\%* & 2.15 & 1.34 & 0.89 \\
\hline AP ppm* & 3.97 & 3.85 & 5.39 \\
\hline \multicolumn{4}{|c|}{ Soluble cations meq/L } \\
\hline $\mathrm{Na}^{+}$ & 12.30 & 10.89 & 7.93 \\
\hline $\mathrm{K}^{+}$ & 0.15 & 0.16 & 0.13 \\
\hline $\mathrm{Ca}^{++}$ & 5.36 & 4.39 & 3.28 \\
\hline $\mathrm{Mg}^{++}$ & 4.11 & 4.03 & 3.96 \\
\hline \multicolumn{4}{|c|}{ Soluble anions (meq/L) } \\
\hline $\mathrm{Cl}^{-}$ & 14.21 & 12.20 & 8.14 \\
\hline $\mathrm{HCO}_{3}^{-}$ & 3.50 & 3.41 & 3.15 \\
\hline $\mathrm{CO}_{3}^{--}$ & 0.00 & 0.00 & 0.00 \\
\hline $\mathrm{SO}_{4}^{--}$ & 4.21 & 3.86 & 4.01 \\
\hline
\end{tabular}

$\mathrm{SAR}=$ Sodium absorption ratio, $\mathrm{OM}=$ Organic $\mathrm{Matter}, \mathrm{AP}=$ Available phosphorus.

Also, data of air and soil temperature, relative humidity and evaporation rate are presented in Table 2. The objective of this experiment was to evaluate and compare the behavior of the three peach cultivars specially bud fertility. In addition, the distribution of dormant, vegetative and flower buds on different position of one-year old shoots hoping to give useful information helping peach growers in pruning their trees. Each cultivar treatment was represented by five trees selected to be healthy, as uniform as possible in size and vigour.

Egypt. J. Hort. Vol. 42, No.1 (2015) 
TABLE 2. Air and soil temperature $\left({ }^{\circ} \mathrm{C}\right)$, relative humidity $\%$ and evaporation rate (\%) at Kafrelsheikh region.*

\begin{tabular}{|c|c|c|c|c|c|c|c|c|c|c|c|c|}
\hline \multirow[t]{3}{*}{ Month } & \multicolumn{2}{|c|}{$\begin{array}{c}\text { Air } \\
\text { temperature } \\
\left({ }^{\circ} \mathrm{C}\right) \\
\end{array}$} & \multirow[t]{2}{*}{$\begin{array}{c}\mathbf{R H} \\
\%\end{array}$} & \multicolumn{2}{|c|}{$\begin{array}{c}\text { Av. soil } \\
\text { temp. }{ }^{\circ} \mathrm{C}\end{array}$} & \multirow[t]{2}{*}{$\begin{array}{c}\text { Evap. } \\
\%\end{array}$} & \multicolumn{2}{|c|}{$\begin{array}{c}\text { Air } \\
\text { temperature } \\
\left({ }^{\circ} \mathrm{C}\right)\end{array}$} & \multirow[t]{2}{*}{$\begin{array}{c}\mathbf{R H} \\
\%\end{array}$} & \multicolumn{2}{|c|}{$\begin{array}{l}\text { Av. soil } \\
\text { temp. }{ }^{\circ} \mathrm{C}\end{array}$} & \multirow[t]{2}{*}{$\begin{array}{c}\text { Evap. } \\
\%\end{array}$} \\
\hline & Max. & Min & & Max. & Min & & Max. & Min & & Max. & Min & \\
\hline & \multicolumn{6}{|c|}{2007} & \multicolumn{6}{|c|}{2008} \\
\hline Jan. & 18.7 & 6.1 & 71.0 & 13.5 & 10.7 & 3.6 & 19.4 & 5.6 & 69.5 & 13.7 & 9.4 & 3.2 \\
\hline Feb. & 16.3 & 6.0 & 70.2 & 13.4 & 10.9 & 3.1 & 17.2 & 7.1 & 71.0 & 15.3 & 9.1 & 2.6 \\
\hline Mar. & 19.7 & 6.5 & 63.1 & 15.8 & 14.0 & 2.6 & 22.7 & 8.7 & 68.1 & 19.8 & 14.2 & 2.8 \\
\hline Apr. & 15.3 & 10.1 & 66.8 & 21.1 & 18.7 & 3.5 & 26.2 & 11.1 & 64.8 & 24.3 & 17.5 & 5.1 \\
\hline May. & 29.7 & 16.4 & 64.4 & 26.0 & 25.1 & 5.1 & 27.6 & 17.1 & 63.3 & 27.6 & 20.5 & 4.7 \\
\hline June & 30.0 & 18.6 & 66.9 & 28.7 & 26.5 & 6.1 & 29.5 & 18.7 & 69.7 & 27.8 & 24.2 & 5.9 \\
\hline July & 31.1 & 21.0 & 69.1 & 30.5 & 28.7 & 6.5 & 32.7 & 24.9 & 72.0 & 30.4 & 25.4 & 5.6 \\
\hline Aug. & 32.7 & 22.7 & 71.0 & 31.4 & 28.6 & 6.5 & 32.6 & 24.8 & 71.1 & 30.5 & 24.1 & 6.1 \\
\hline Sept. & 29.6 & 20.6 & 65.4 & 26.7 & 24.5 & 6.0 & 30.0 & 20.1 & 67.5 & 24.6 & 22.1 & 5.6 \\
\hline Oct. & 27.7 & 15.8 & 67.6 & 24.7 & 22.3 & 4.8 & 29.0 & 19.2 & 69.9 & 22.9 & 20.7 & 4.3 \\
\hline Nov. & 24.7 & 12.3 & 70.1 & 23.4 & 19.7 & 4.4 & 24.3 & 17.8 & 70.4 & 20.3 & 16.5 & 4.1 \\
\hline Dec. & 20.1 & 8.7 & 68.8 & 17.2 & 10.5 & 4.7 & 20.2 & 10.7 & 68.4 & 12.6 & 11.2 & 3.8 \\
\hline
\end{tabular}

* According to daily weather observations of Seidy Salem Weather Station

Thus, fifteen peach trees were chosen and used in this experiment ( 3 cultivars $x 5$ trees). Ten one-year old shoots in the four directions were labeled and left unpruned on each tree of each cultivar for testing bud fertility as a number of flower buds/shoot length or per node. Evaluation and comparison among the three peach cultivars included the following parameters:

- Dates of foliation and defoliation as well as vegetative growth period (days)

- Dates of flower bud breaking, full bloom and fruit maturity as well as fruit development period (days).

- Number and percentage of total, dormant, vegetative and flower buds.

- Shoot and internode length $(\mathrm{cm})$ and number of internodes per shoot.

- Number and percentage of flower buds on different positions (basal, middle and terminal) of one-year old shoots.

- Distribution of dormant, vegetative and flower buds on different position of one-year old shoots.

- The fertility was evaluated by recording the number of flower buds per one $\mathrm{cm}$ of shoot and per node.

- Date of fruit maturity and harvest periods (days).

- Yield.

- Physical and chemical fruit properties.

A randomized complete block design was used. The obtained data were subjected to statistical analysis according to Snedecor and Cochran (1990) and the least significant different (LSD) test was used for comparing between averages. 


\section{Results and Discussion}

Vegetative growth

Dates of vegetative bud breaking on different directions of trees

It is clear from the data of Table 3 that, vegetative buds of Florida Prince cultivar started breaking in all direction approximately at the same time on (79/1, 9-4/1).However vegetative buds of Early Grand and Desert Red peach cultivars started breaking in the north direction early on $(8 / 1,12 / 1)$ and $(11 / 1$, $12 / 1$ ) in both seasons, respectively but buds in the east and west directly started breaking together on $(10 / 1,13-14 / 1)$ and $(12 / 1,15-16 / 1)$, while buds of south direction started breaking later on $(16 / 1,17 / 1)$ and $(17 / 1,17 / 1)$ in both seasons, respectively. This effect could be due to the reduction in temperature in the north direction compared to south one of winter. These results are in harmony with those obtained by Mohamed (1995) who evaluated some peach cultivars and mentioned that vegetative buds of Florida Bell started opening in the north direction early on Feb. $2^{\text {nd }}$. Moreover, buds in the east and west directions started opening together on Feb. $5^{\text {th }}$, while, buds in south direction started opening lately on Feb. $9^{\text {th }}$.

AS for the effect of cultivar, the data revealed that, all the three tested cultivars started breaking early in January due to its low chilling requirements. In addition "Florida Prince" started vegetative bud very early and "Early Grand" was intermide in starting while Desert Red started later in both seasons.The present results are in line with those reported by Mansour and Stino (1987b). They indicated that vegetative bud break occurred about one week earlier in "Early Grand" than in "Desert Gold". Moreover, Shaltout (1987) indicated that, "Florida Prince" required about $100-150$ hours at $7.2^{\circ} \mathrm{C}$ to release its bud from dormancy and he added that the time of vegetative bud break of Florida Prince cultivars was on Jan. 25 in 1986 and Feb. 1 in 1987 in Nobaria, Beheira Governorate, Egypt.

TABLE 3. Dates of vegetative bud breaking in different direction of trees of some peach cultivars in 2007 and 2008 seasons.

\begin{tabular}{|c|c|c|c|c|c|}
\hline \multirow{2}{*}{ Cultivar } & \multicolumn{4}{|c|}{ Dates of vegetative bud breaking } & \multirow{2}{*}{ Main } \\
\hline & East & West & North & South & \\
\hline \multicolumn{6}{|c|}{2007 season } \\
\hline Florida prince & Jan. 8 & Jan. 8 & Jan. 7 & Jan. 9 & Jan. 8 \\
\hline Early Grand & Jan. 10 & Jan. 10 & Jan. 8 & Jan. 16 & Jan. 11 \\
\hline Desert red & Jan. 12 & Jan. 12 & Jan. 11 & Jan. 17 & Jan. 13 \\
\hline \multicolumn{6}{|c|}{2008 season } \\
\hline Florida prince & Jan. 10 & Jan. 10 & Jan. 9 & Jan. 11 & Jan. 10 \\
\hline Early Grand & Jan. 14 & Jan. 13 & Jan. 12 & Jan. 17 & Jan. 14 \\
\hline Desert red & Jan. 16 & Jan. 15 & Jan. 12 & Jan. 17 & Jan. 15 \\
\hline
\end{tabular}

Egypt. J. Hort. Vol. 42, No.1 (2015) 
Defoliation dates and vegetative growth periods

Data presented in Table 4 indicated that defoliation occurred early in "Florida Prince" at (Oct. 20 ${ }^{\text {th }}$ and Oct. 16 ${ }^{\text {th }}$ ) and occurred intermide in "Early Grand" at (Oct. 25 $5^{\text {th }}$ and Oct. $23^{\text {rd }}$ ) while occurred latterly in "Desert Red" at (Nov. $5^{\text {th }}$ and Nov. $4^{\text {th }}$ ) in both seasons, respectively.. Similar results were reported by Mansour and Stino (1987) who found that leaf abscission of Meadowlark peach cultivar under El-Kanater conditions, advanced for about 10 days in the second than in the first seas on (98\% of leaf abscission occurred in 30 Nov., 1984 while in 20 Nov., 1985).

TABLE 4. Defoliation dates and vegetative growth periods (days) of some peach cultivars in 2007 and 2008 seasons.

\begin{tabular}{|l|c|c|c|c|}
\hline \multirow{2}{*}{ Cultivars } & \multicolumn{2}{|c|}{ 2007 season } & \multicolumn{2}{c|}{ 2008 season } \\
\cline { 2 - 5 } & $\begin{array}{c}\text { Defoliation } \\
\text { dates }\end{array}$ & VGP (days)* & $\begin{array}{c}\text { Defoliation } \\
\text { dates }\end{array}$ & VGP (days)* \\
\hline Florida prince & Oct. 20 & 285 & Oct. 16 & 280 \\
\hline Early Grand & Oct. 25 & 287 & Oct. 23 & 282 \\
\hline Desert Red & Nov. 5 & 296 & Nov. 4 & 293 \\
\hline LSD 0.05 & - & 2.17 & - & 2.11 \\
LSD 0.01 & - & 3.16 & - & 3.07 \\
\hline
\end{tabular}

* VGP = Vegetative growth period (days)

Concerning vegetative growth period (VGP), it is clear that, Florida Prince and Early Grand peach cultivars recorded the shortest vegetative growth periods respectively. While, Desert Red Peach cultivar counted the longest vegetative growth in both seasons, respectively. This variation among the three tested peach cultivars in vegetative growth period (days) mainly attributed to Gentic background. Such results are in harmony with those obtained by Mansour and Stino (1987). However, change of weather from year to other could interfere with this effect.

\section{Number and percentage of buds types}

Data of Table 5 show that, the highest total number of buds per one year old shoot belonged to "Florida Prince" (45.7 \& 41.3) followed by "Desert Red" (41.4 \& 39.9) while, the least number came from Early Grand (39.1 \& 37.2) in 2007 and 2008 seasons, respectively.The data also exhibited that, Florida Prince cv produced highest significant number and percentage of flower buds and lowest significant number and percentage of vegetative and dormant buds with comparison to Early Grand and Desert Red peach cultivars in both seasons. The differences in the percentages of dormant, vegetative and flower buds between Early Grand and desert Red cultivars were not significant in both seasons. These results could be mainly attributed to genetic variation among the tested peach cultivars. These findings are in general agreement with those reported by El-Baz et al. (2007) who evaluated three peach cultivars namely Florida Prince, Florida Gold and Early Grand, indicated that, under El-Wahat El-Baharia, Giza conditions. The percentage of 
leaf bud was the highest in Florida Gold (32.8 \& 35.4\%) but Early Grand gave the lowest percentage $(30.4 \& 30.6 \%)$ in 2004 and 2005 seasons, respectively. However, the highest floral buds percentage obtained with Early Grand (60.8 $\& 55.0 \%$ ) but Florida Prince gave the lowest percentage (59.0 \& 52.7\%). Similar results were also reported by Eliwa (2005) who indicated that flower buds \% was significantly higher than vegetative buds \% in all selected strains of "Mit Ghamr" peach except late "Sultani" and "Neely" strains. However, "Neely" and "Fark" strains recorded the highest values of dormant buds \% compared to other strains.

TABLE 5. Number and percentage of buds type of some peach cultivars in 2007 and 2008 seasons.

\begin{tabular}{|l|c|c|c|c|c|c|c|c|}
\hline \multirow{2}{*}{ Cultivar } & \multicolumn{2}{|c|}{ Total buds } & \multicolumn{2}{|c|}{ Dormant buds } & \multicolumn{2}{l|}{ Vegetative buds } & \multicolumn{2}{c|}{ Flower buds } \\
\cline { 2 - 9 } & No. & \% & No. & \% & No. & \% & No. & \% \\
\hline \multicolumn{8}{|c|}{$\mathbf{2 0 0 7}$ season } \\
\hline Florida prince & 45.7 & 100 & 5.6 & 12.25 & 14.7 & 32.17 & 25.4 & 55.58 \\
\hline Early Grand & 39.1 & 100 & 7.1 & 18.16 & 14.5 & 37.08 & 17.5 & 44.76 \\
\hline Dessert Red & 41.4 & 100 & 6.9 & 16.67 & 15.9 & 38.40 & 18.6 & 44.93 \\
\hline LSD 0.01 & 0.31 & - & 0.16 & 1.31 & 0.21 & 1.78 & 1.13 & 1.67 \\
LSD 0.05 & 0.45 & - & 0.23 & 1.91 & 0.31 & 2.59 & 1.64 & 2.43 \\
\hline \multicolumn{8}{|c|}{$\mathbf{2 0 0 8}$ season } \\
\hline Florida prince & 41.3 & 100 & 4.9 & 11.86 & 14.4 & 34.87 & 22.0 & 53.27 \\
\hline Early Grand & 37.2 & 100 & 6.7 & 18.01 & 13.9 & 37.37 & 16.6 & 44.62 \\
\hline Dessert Red & 39.9 & 100 & 6.4 & 16.04 & 15.2 & 38.10 & 18.3 & 45.86 \\
\hline LSD 0.01 & 0.33 & - & 0.17 & 1.91 & 0.18 & 1.89 & 1.11 & 1.50 \\
LSD 0.05 & 0.48 & - & 0.25 & 2.78 & 0.26 & 2.75 & 1.61 & 2.18 \\
\hline
\end{tabular}

* Total buds per one year old shoot.

\section{Shoot growth}

Data illustrated in Table 6 clear that, there were significant differences obtained between cultivars in shoot and internode length in both seasons. The highest values of shoot length recorded with Florida Prince cultivar (52.95 \& $55.62 \mathrm{~cm})$ followed by Desert Red cultivar $(47.72 \& 51.41 \mathrm{~cm})$ while, the lowest values belonged to "Early Grand" (45.84 \& 49.73) in 2007 and 2008 seasons, respectively. The obtained results herein are in line with those reported by Hussien (2009) who indicated that, the highest average shoot length obtained with Bakkeveld peach cultivar $(73.06 \mathrm{~cm})$ while the shortest shoot recorded with "De Wet" cultivar $(55.24 \mathrm{~cm})$. As for internode length, the parameter take the same trend as influenced with cultivar and the longest internode came from "Florida Prince" descendingly followed by "Desert Red" cultivar. Meanwhile, Early Grand produced the shortest internode.

As for number of internodes per shoot, it is clear that the highest number produced with Florida Prince and Early Grand cultivars without significant differences between them in both seasons, while the least number belonged to

Egypt. J. Hort. Vol. 42, No.1 (2015) 
Desert Red peach cultivar. Similar results were also obtained by Mohamed (1995) who mentioned that Florida Beauty, "Sun Gold" and Florida Belle gave the highest number of internodes followed by La Peacher and La Festival. However, the least number was obtained by Texstar and June Gold peach cultivar. Also, Hussien (2009) reported that "De Wet" peach cv. gave the highest number of internodes per shoot followed by Hermosilla (29.92) but the least number obtained by Desert Pearl and Bokkeveld (22.67 and 22.17, respectively).

TABLE 6. Shoot and internode lengths and number of internode per shoot of some peach cultivar in 2007 and 2008 seasons.

\begin{tabular}{|l|c|c|c|}
\hline \multicolumn{1}{|c|}{ Cultivar } & $\begin{array}{c}\text { Shoot length } \\
(\mathbf{c m})\end{array}$ & $\begin{array}{c}\text { Internode length } \\
(\mathbf{c m})\end{array}$ & No. of internode/shoot \\
\hline \multicolumn{4}{|c|}{$\mathbf{2 0 0 7}$ season } \\
\hline Florida prince & 52.95 & 1.84 & 28.8 \\
\hline Early Grand & 45.84 & 1.62 & 28.3 \\
\hline Dessert Red & 47.72 & 1.73 & 0.68 \\
\hline LSD 0.01 & 1.39 & 0.12 & 0.99 \\
\hline LSD 0.05 & 2.02 & 0.18 & 30.1 \\
\hline \multicolumn{4}{|c|}{ 2008 season } \\
\hline Florida prince & 55.62 & 1.85 & 29.5 \\
\hline Early Grand & 49.73 & 1.69 & 28.2 \\
\hline Dessert Red & 51.41 & 1.82 & 0.71 \\
\hline LSD 0.01 & 1.63 & 0.13 & 1.03 \\
\hline LSD 0.05 & 2.37 & 0.19 & \\
\hline
\end{tabular}

\section{Flowering}

Dates offlower bud breaking at four directions of the tree

Table 7 show that flower buds of the three tested peach cultivars started breaking early in the North direction in (26/12 \& 28/12), (29/12 \& 31.12) and $(11 / \&$ 2/1) for Florida Prince, Early Grand and Desert Red in 2007 and 2008 seasons, respectively. While, flower buds at south direction started breaking lately on $(1 / 1 \& 2 / 1),(3 / 1 \& 5 / 1)$ and $(7 / 1 \& 5 / 1)$ for "Florida Prince", "Early Grand" and "Desert Red" peach cultivars in both seasons, respectively. However, flower buds at east and west directions started breaking on intermediate dates. South is warmer than other sides, which in turn affected chilling requirements and delayed flower bud breaking. Such findings are in agreement with those obtained by Mohamed (1995).

With respect to the main effect of cultivar, the data revealed that flower bud breaking of "Florida Prince" occurred early on (Dec. $28^{\text {th }}$ and Dec. 31 $1^{\text {st }}$ ) followed by Early Grand on (Jan. $1^{\text {st }}$ and June $3^{\text {rd }}$ ) while delayed in Desert Red on (Jan. $4^{\text {th }}$ and Jan. $5^{\text {th }}$ ) in both seasons, respectively. In all tested peach cultivars the time of flower bud breaking occurred on late December and early January in both seasons. These results may be due to the reduction in chilling requirement needed for Florida Prince cultivar. Also, Shaltout (1987) pointed out that flower buds of Florida Prince peach cultivar required less chilling hours 
and terminated their dormancy earlier than the vegetative ones. He added that "Florida Prince" required about $100-150$ hours at $7.2^{\circ} \mathrm{C}$ to release its buds from dormancy. These findings are in agreement with those obtained by Kumar et al. (2004) who indicated that peach cultivars differed in their time required to complete the bud development and the flowering occurred from $10^{\text {th }}$ March for "Tessia Samisto" and from $18^{\text {th }}$ March for "Holes Early".

TABLE 7. Dates of flower bud breaking at different directions of the tree of three peach cultivars in 2007 and 2008 seasons.

\begin{tabular}{|c|c|c|c|c|c|}
\hline \multirow{2}{*}{ Cultivar } & \multicolumn{4}{|c|}{ Dates of flower bud breaking } & \multirow{2}{*}{ Main } \\
\hline & East & West & North & South & \\
\hline \multicolumn{6}{|c|}{2007 season } \\
\hline Florida prince & Dec. 28 & Dec. 28 & Dec. 26 & Jan. 1 & Dec. 28 \\
\hline Early Grand & Jan. 2 & Jan. 1 & Dec. 29 & Jan. 3 & Jan. 1 \\
\hline Desert red & Jan. 4 & Jan. 4 & Jan. 1 & Jan. 7 & Jan. 4 \\
\hline \multicolumn{6}{|c|}{2008 season } \\
\hline Florida prince & Jan. 1 & Dec. 31 & Dec. 28 & Jan. 2 & Dec. 31 \\
\hline Early Grand & Jan. 4 & Jan. 3 & Dec. 31 & Jan. 5 & Jan. 3 \\
\hline Desert red & Jan. 5 & Jan. 5 & Jan. 2 & Jan. 8 & Jan. 5 \\
\hline
\end{tabular}

Number and percentage offlower buds on different positions of the shoot

It is evident from data presented in Table 8 that all cultivars borne flowers on one year old shoots. However, the position of flower bud on the shoot varied from cultivar to other.

TABLE 8. Number and percentage of flower buds on different position on one year old shoot of some peach cultivars in 2007 and 2008 seasons.

\begin{tabular}{|l|c|c|c|c|c|c|}
\hline \multirow{2}{*}{ Cultivar } & \multicolumn{2}{c|}{ Basal part } & \multicolumn{2}{c|}{ Middle part } & \multicolumn{2}{c|}{ Terminal part } \\
\cline { 2 - 7 } & No. & \% & No. & \% & No. & \% \\
\hline \multicolumn{7}{|c|}{ 2007 season } \\
\hline Florida prince & 14.3 & 57.20 & 7.8 & 30.71 & 3.3 & 12.99 \\
\hline Early Grand & 5.6 & 32.00 & 6.0 & 34.29 & 5.9 & 33.71 \\
\hline Dessert Red & 4.9 & 26.34 & 8.1 & 43.55 & 5.6 & 30.11 \\
\hline LSD 0.01 & 1.75 & 2.63 & 0.74 & 1.31 & 0.72 & 1.89 \\
LSD 0.05 & 2.55 & 3.83 & 1.08 & 1.91 & 1.05 & 2.75 \\
\hline \multicolumn{7}{|c|}{ 2008 season } \\
\hline Florida prince & 12.5 & 56.82 & 7.0 & 31.82 & 2.5 & 11.36 \\
\hline Early Grand & 5.5 & 32.53 & 5.7 & 34.34 & 5.4 & 33.13 \\
\hline Dessert Red & 4.3 & 23.50 & 8.2 & 44.81 & 5.8 & 31.69 \\
\hline LSD 0.01 & 1.36 & 2.61 & 0.65 & 1.51 & 0.78 & 1.86 \\
LSD 0.05 & 1.98 & 3.80 & 0.95 & 2.98 & 1.13 & 2.71 \\
\hline
\end{tabular}

Total buds per one year old shoot.

Egypt. J. Hort. Vol. 42, No.1 (2015) 
Early Grand cultivar borne all its flower buds along of one year old shoots without any effect of the positions on the shoot. The number of flower buds were (5.6 and 6.0 and 5.9) and (5.5, 5.7 and 5.4) and the percentage of flower buds were (32.00, 34.29 and 33.71) and (32.53, 34.34 and 33.13\%) at basal, middle and terminal parts of the shoot in both seasons, respectively. However, Florida Prince cultivar borne most of flower buds on the basal part of shoots (14.3 and 12.5) with the percentage of (57.20 and 56.82\%), in both seasons, respectively. While Desert Red peach cultivar borne most of flower buds at the middle part of the shoot (8.1 and 8.2) with the percentage of (43.55 and 44.81\%) in the first and second seasons, respectively. These variation in number and percentage of flower buds located at different position on 1-year old shoot might be due to genetic makeup. Similar results were also reported by Mohamed (1995) who indicated that the number of flower buds of eight evaluated peach cultivars located at different position of one year old shoot were different. A high number of flower buds were formed on the middle part of shoots for "La Festival" and "Florida Beauty" but most flowers of "Florida Gold", "Texstar", "Sun Gold" and "Florida Belle" were carried out on the terminal two thirds. Meanwhile, the flower buds of La Peacher were carried along shoots without any effect of the position of the shoot.

\section{Distribution of buds type at different position of the shoot}

Data illustrated in Fig. 1 show distribution of dormant vegetative and flower buds on different position of one year old shoots of the three tested peach cultivar as average 2007 and 2008 seasons. It is clear that the highest average number of flower buds of "Florida Prince" carried out on the basal parts of the shoot. Meanwhile, the most flower buds of "Desert Red" were carried out on the middle part. Furthermore, the flower buds of "Early Grand" were found along the shoot with respect to vegetative buds, it is clear that, the highest average number of all tested peach cultivars were carried out on basal and middle parts but the highest number of dormant buds always carried out on the basal part of one year old shoots. These findings are in harmony with those obtained by Mohamed (1995) who found that the percentage of vegetative buds obtained with "Florida Beauty" gave the highest values ( $88.1 \%$ in 1992 and 75.3\% in 1993) as compared to another cultivars followed closely with "Sun Gold" (85.3\% in 1992 and $72.2 \%$ in 1993), while the least percentage recorded in June Gold (50\% in 1992 and 39.2\% in 1993). On the other hand Florida Belle, "Florida Beauty and "Sun Gold" gave the highest opening percentage of flower bud $(87.95,89.5,88.9 \%$ in 1992 and $72.4,77.5,74.2 \%$ in 1997) while the least percentage was obtained with June Gold (51.7adn 42.2\%) in 1992 and 1993, respectively.

Flower bud density (FDB)

Data of Fig. 2 and 3 show fertility index and number of flower buds per node of some peach cultivars in 2007 and 2008 seasons.

Concerning fertility index as number of flower buds per $1 \mathrm{~cm}$ of shoots, the data disclosed that Florida Prince cultivar obtained the highest values in both seasons (0.48 and 0.40) compared to "Early Grand" and "Desert Red". The least values 
recorded with "Early Grand" (0.38 and 0.33$)$, while "Desert Red" showed an intermediate fertility index (0.39 and 0.36). The differences between "Desert Red" and "Early Grand" was only significant in the second season. The highest fertility index in "Florida Prince" may be due to its ability to produce more flowering buds. Such variation in fertility index were also noticed by Barone et al. (1995) on four peach cultivars who found that "Maravilha" had the greatest flower density (flower buds/cm) followed by "Florida Star". Also, Sottile et al. (2003) on 18 almond cultivars grown in Italy mentioned that, the highest values of fertility index belonged to "Don Pitrio" (2-27) followed by "Bottara" (1-65) while the least values recorded with Buscarina (0-29). As for number of flower buds per node, the obtained data exhibited that, this variable take the same trend of fertility index as influenced by the cultivar. "Florida Prince" showed the highest density ( 0.85 and $0.71)$ followed by "Desert Red" $(0.65$ and 0.63$)$ then came "Early Grand" $(0.60$ and $0.54)$. The differences among the three studied peach cultivar were significant in both seasons. Similar variation in density of flower buds were reported by Hussien (2009) who evaluated some peach cultivars and indicated that "Hermosillo" cultivar had the highest density of buds compared to other cultivars.

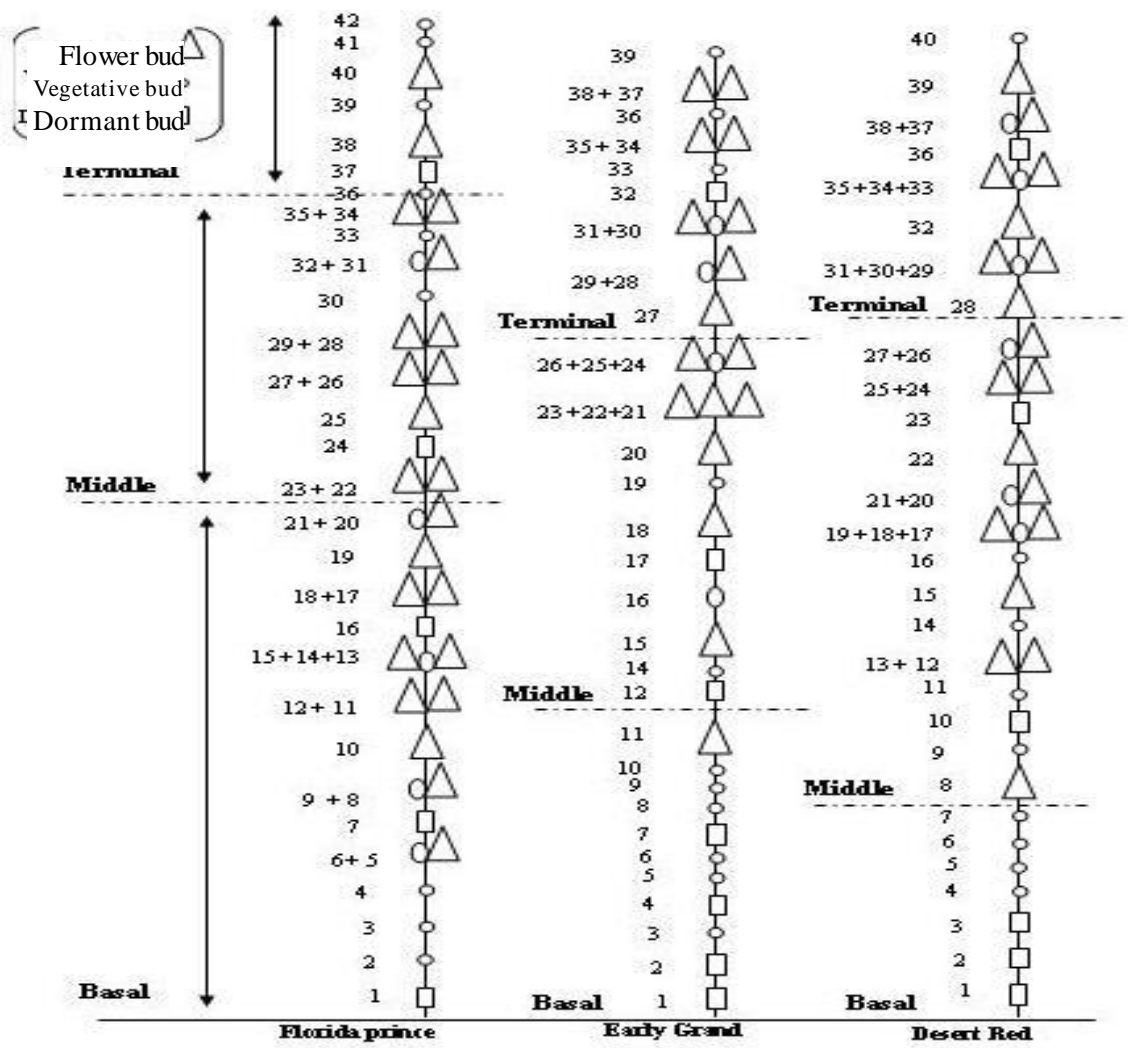

Fig. 1. Distribution of dormant, vegetative and flower buds on different position on one year-old shoots of three peach cultivar (average 2007 and 2008 season . 


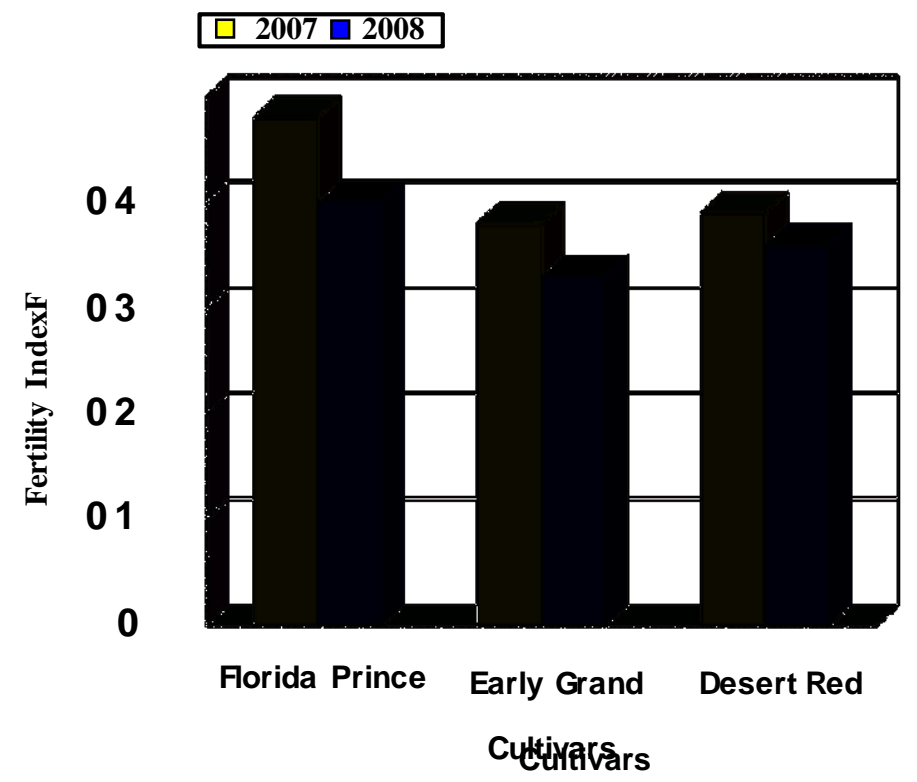

Fig. 2. Fertility index of some peach cultivars in 2007 and 2008 seasons .

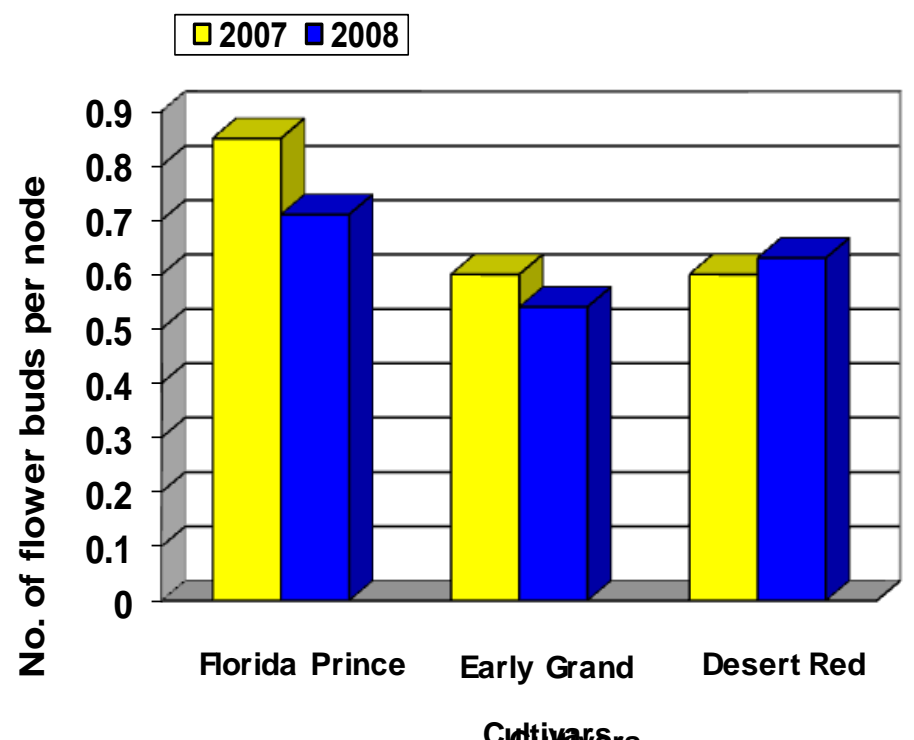

Fig. 3. Number of flower buds pernode of some peach cultivars in 2007 and 2008 seasons.

Egypt. J. Hort. Vol. 42, No.1 (2015) 
Full bloom

The full blooming stage is recorded when the opened flowers reached $50 \%$ or more. The full blooming stage was evident early in "Florida Prince" cultivar on January $27^{\text {th }}$ and $25^{\text {th }}$, respectively in both seasons, followed by "Early Grand" on February $1^{\text {st }}$ and January $30^{\text {th }}$ in both seasons. While, the full bloom of "Desert Red" occurred on February $3^{\text {rd }}$ and January $31^{\text {st }}$ in the first and second seasons as shown in Table 9 . Generally, the results indicated that in the three cultivars, full bloom stage have occurred earlier in the second season than the first one. "Florida Prince" cultivar which required 100-150 hours chill units for bud break, according to Shaltout (1987) have bloomed earlier than the medium chilling requirement cultivars. These results are in harmony with those obtained by Aly (1988) who found that "Florida Belle" and "Florida Prince" usually blooming early at the same time by late January. Meanwhile, "Florida Gold" blooming later than the other cultivars need higher chilling requirement. Also, Sherman and Lyrene (1989) found that full bloom of Florida Star peach cultivar occurs during early February about 3 days after "Florida Prince".

TABLE 9. Dates of full bloom and maturity and fruit development period.

\begin{tabular}{|l|c|c|c|}
\hline Cultivar & $\begin{array}{c}\text { Date of full bloom } \\
\text { (FB) }\end{array}$ & Date of maturity & FDB* (days) \\
\hline \multicolumn{5}{|c|}{$\mathbf{2 0 0 7}$ seasons } \\
\hline Florida prince & Jan. 27 & Apr. 4 & 69 \\
\hline Early Grand & Feb. 1 & May 3 & 91 \\
\hline Dessert Red & Feb. 3 & May 19 & 3.01 \\
\hline LSD 0.01 & - & - & 4.38 \\
LSD 0.05 & - & Apr. 6 & 72 \\
\hline \multicolumn{5}{|c|}{ 2008 season } & 94 \\
\hline Florida prince & Jan. 25 & May 3 & 110 \\
\hline Early Grand & Jan. 30 & - & 3.11 \\
\hline Dessert Red & Jan. 31 & - & 4.52 \\
\hline LSD 0.01 & - & May 20 & \\
LSD 0.05 & - &
\end{tabular}

FDP: fruit development period (No. of day s from full bloom to maturity).

\section{Fruiting}

Fruit maturity

The present data of Table 10 indicated that the number of days required for fruit maturity from full bloom had varied according to the cultivars. In the first season, the fruit maturity of "Florida Prince" occurred by early April $4^{\text {th }}$ after 69 days from full bloom, while the fruits of "Early Grand" matured at May $3^{\text {rd }}$ after 91 days. On the other side, fruits of "Desert Red" required a longer maturing period 111 days from full bloom.In the second season fruit maturity occurred slightly later than first one. The fruits of "Florida Prince" were matured by early April $6^{\text {th }}$ after 72 days from full bloom followed by "Early Grand" by early May $3^{\text {rd }}$ after 94 days and "Desert Red" by late May $20^{\text {th }}$ after 110 days from full bloom.Peach fruit development had three distinct stages with a double sigmoidal growth curve and there was a positive correlation between the period of pit hardening (Stage 11) and the number of days required for maturity. Whereas, "Florida Prince" which considered to have the shortest maturity period had the shortest period of pit hardening (Aly, 1988). The previous studies indicated that

Egypt. J. Hort. Vol. 42, No.1 (2015) 
the fruit maturity of "Florida Prince" occurred during late April to early May after about 79.84 days from full bloom under Egyptian conditions (Mansour and Stino, 1987; Shaltout, 1987 and Aly, 1988). However, fruit maturity of Early Grand occurred from 30 April to 4 May as mentioned by Dozier et al. (1998).

\section{Harvest dates and periods}

With respect to harvest dates and periods (days) the data obtained in Table 10 indicated that the tested peach cultivar varied in their harvest dates and periods. It was found that, under North Delta condition, "Florida Prince" is early harvested from April $4^{\text {th }}$ to April $20^{\text {th }}$ (16 days) in the first season and during April $6^{\text {th }}-$ April $21^{\text {st }}$ (15 days) in the second one followed by "Early Grand" which was harvested during May $3^{\text {rd }}-$ May $20^{\text {th }}$ (17 days) and May3rd - May $21^{\text {st }}$ (18 days) in 2007 and 2008 seasons, respectively. Whereas, "Desert Red" was harvested later during May $19^{\text {th }}-$ June $7^{\text {th }}$ for 19 days and during May $18^{\text {th }}$ - June $7^{\text {th }}$ for 20 days. Moreover, "Desert Red" peach cultivar showed the longest harvest period nearly three weeks (19-20 days) from the end of May to the first week of June followed by "Early Grand" (17-18 days) during first to third weeks of May. Meanwhile, "Florida Prince" recorded the shortest harvest period (16-151 days) during first to third week of April in both seasons.

These results herein are in line with these obtained by Shaltout (1987) who concluded that, the harvest period of "Florida Prince" ranged between 2/5 to 21/5 in 1986 and 1/5 to 10/5 in 1987 season under Egyptian conditions. Furthermore, Dozier et al. (1998) found that the first harvest date was from April $4^{\text {th }}$ to May $4^{\text {th }}$ for Early Grand peach cultivar.

Generally, "Florida Prince" considered the suitable cultivar under the conditions of North Delta due to its low chilling requirements which in turn reached full bloom stage early on January $27^{\text {th }}$ and January $25^{\text {th }}$, its fruit maturity occurred by early April after (69-72 day) from full bloom and harvested from April $4^{\text {th }}$ to April $20^{\text {th }}$ and from April $6^{\text {th }}$ to April $21^{\text {st }}$ ) in the first and second seasons, respectively (Table 10).

TABLE 10. Harvest dates, period and yield of the three peach cultivars in 2007 and 2008.

\begin{tabular}{|l|c|c|c|c|}
\hline \multicolumn{1}{|c|}{ Cultivars } & Harvest dates & $\begin{array}{c}\text { Harvest } \\
\text { period (days) }\end{array}$ & $\begin{array}{c}\text { No. of } \\
\text { fruits/tree }\end{array}$ & $\begin{array}{c}\text { Yield } \\
\text { (kg/tree) }\end{array}$ \\
\hline \multicolumn{5}{|c|}{ 2007 season } \\
\hline Florida prince & Apr. 4-Apr.20 & 16 & 482 & 38.15 \\
\hline Early Grand & May 3-May 20 & 17 & 426 & 40.61 \\
\hline Desert Red & May 19-June 7 & 19 & 461 & 42.14 \\
\hline LSD 0.05 & - & 0.97 & 4.01 & 1.12 \\
LSD 0.01 & - & 1.41 & 5.83 & 1.62 \\
\hline \multicolumn{5}{|c|}{$\mathbf{2 0 0 8}$ season } \\
\hline Florida prince & Apr. 6-Apr.21 & 15 & 412 & 34.90 \\
\hline Early Grand & May 3-May 21 & 18 & 357 & 36.38 \\
\hline Desert Red & May 18-June 7 & 20 & 405 & 38.82 \\
\hline LSD 0.05 & 0.87 & 5.12 & 1.09 \\
LSD 0.01 & 1.27 & 7.44 & 1.59 \\
\hline
\end{tabular}

Egypt. J. Hort. Vol. 42, No.1 (2015) 
Yield

Number of fruits/tree

According to data presented in Table 10, it is clear that, "Florida Prince" cultivar produced significantly the highest number of fruits per tree followed by "Desert Red" (461adn 405) while, "Early Grand" gave the least number in both season. The highest number of fruits recorded for "Florida Prince" in comparis on with other cultivars could be attributed to the highest fertility index of this cultivar.These results are in harmony with those obtained by Ahmed et al. (2002) who indicated that, maximum number of fruits 945/tree was were recorded for "Early Grand" which was significantly higher than Florida Sun 746/tree.

\section{Yield $(\mathrm{kg} /$ tree $)$}

Concerning the yield as $(\mathrm{kg} / \mathrm{tree})$ of the three peach cultivars, the present data in Table (10) exhibited that, "Desert Red" cultivars produced maximum yield per tree ( 42.14 and $38.82 \mathrm{~kg}$ ). Meanwhile, "Florida Prince" gave minimum yield (38.15 and $34.90 \mathrm{~kg}$ ). However, "Early Grand" gave the intermediate yield (40.61 and $36.38 \mathrm{~kg}$ ) in 2007 and 2008 seasons, respectively. The reduction in "Florida Prince" yield as $\mathrm{kg} /$ tree may be due to higher number of small fruits, since it recorded the highest number of fruits/tree in both seasons.These findings are in complete agreement with those obtained by El-Baz et al. (2007) who mentioned that, "Florida Prince" produced the lowest average yield (42.9 and $33.70 \mathrm{~kg} /$ tree) in El-Wahat El-Baharia and El-Badrashin regions, respectively. While, El-Etraby (1996) indicated that "Desert Gold" cultivar gave the highest yield $80.75 \mathrm{~kg} /$ tree followed by "Early Grand" cultivar $78.50 \mathrm{~kg} / \mathrm{tree}$ and "Florida Sun" cultivar was the lowest one $62.73 \mathrm{~kg} /$ tree.

Fruit quality:

Physical fruit properties:

Fruit weight $(g)$ :

Data of Table 11 disclosed that, "Early Grand" cultivar gave the highest significant values (95.32 and $101.91 \mathrm{~g}$ ) as well as "Desert Red" (91.41 and 95.86), while, "Florida Prince" showed the least significant average of fruit weight (79.15 and 84.27) during the first and second seasons, respectively. These variation in fruit weight of among peach cultivars could be mainly attributed to genetic background. These findings herein are in line with the previous studies of El-Baz et al. (2007) who found that the highest fruit weight was obtained from "Early Grand" (98.0-102.3 g). While "Florida Prince" cultivar gave the lowest one $(90.4-93.9 \mathrm{~g})$. However, El-Khoreiby et al. (2011) mentioned that "Desert Red" showed an intermediate fruit weight. Also, Shaltout (1987) found that "Florida Prince" weighed about (80.5 and $99.5 \mathrm{~g})$ in the two successive seasons of 1986 and 1987 in El-Nobaria region.

\section{Fruit size and dimensions}

In the two studied seasons, the effect of cultivars on fruit size $\left(\mathrm{cm}^{3}\right)$ showed that, the largest fruits and highest significant values in fruit length observed in "Early Grand followed by "Desert Red" while the smallest was "Florida 
Princein both seasons.Such results are in harmony with the findings of Aly (1988) and Hussien (2009). reported that "Florida Prince" showed the least significant size.

TABLE 11. Physical fruit properties of some peach cultivars in 2007 and 2008 seasons .

\begin{tabular}{|l|c|c|c|c|c|c|}
\hline \multicolumn{1}{|c|}{ Cultivar } & $\begin{array}{c}\text { Fruit } \\
\text { weight }(\mathbf{g})\end{array}$ & $\begin{array}{c}\text { Fruit size } \\
\left(\mathbf{c m}^{\mathbf{3}}\right)\end{array}$ & $\begin{array}{c}\text { Fruit } \\
\text { length } \\
(\mathbf{c m})\end{array}$ & $\begin{array}{c}\text { Fruit } \\
\text { diameter } \\
\left(\mathbf{c m}^{\mathbf{2}}\right)\end{array}$ & $\begin{array}{c}\text { Fruit } \\
\text { shape (LD } \\
\text { ratio) }\end{array}$ & $\begin{array}{c}\text { Fruit } \\
\text { firmness } \\
\left(\mathbf{L} / \mathbf{i n}^{2}\right)\end{array}$ \\
\hline \multicolumn{7}{|c|}{$\mathbf{2 0 0 7}$ season } \\
\hline Florida prince & 79.15 & 77.57 & 5.27 & 5.56 & 0.95 & 12.79 \\
\hline Early Grand & 95.32 & 93.09 & 5.56 & 6.01 & 0.93 & 14.86 \\
\hline Desert Red & 91.41 & 89.94 & 5.47 & 5.89 & 0.93 & 12.96 \\
\hline LSD 0.05 & 2.02 & 1.96 & 0.019 & 0.022 & NS & 0.78 \\
LSD 0.01 & 2.94 & 2.85 & 0.027 & 0.032 & & 1.13 \\
\hline \multicolumn{7}{|c|}{$\mathbf{2 0 0 8}$ season } \\
\hline Florida prince & 84.27 & 82.68 & 5.37 & 5.74 & 0.94 & 12.85 \\
\hline Early Grand & 101.91 & 99.59 & 5.68 & 6.15 & 0.92 & 15.98 \\
\hline Desert Red & 95.86 & 93.75 & 5.58 & 6.00 & 0.93 & 13.06 \\
\hline LSD 0.05 & 2.18 & 2.10 & 0.021 & 0.024 & NS & 0.76 \\
LSD 0.01 & 3.17 & 3.05 & 0.031 & 0.036 & & 1.11 \\
\hline
\end{tabular}

Fruit shape index

Shape is a function of length and diameter of the fruit, Table (12) show that there were no significant differences among the tested cultivars in fruit shape index in both seasons. Fruit shape of all cultivars nearly ranged between $(0.92-$ 0.95 ) and seemed to be round. However, it was reported that "Florida Prince" under Egypt conditions is described as nearly round (Mansour and Stino, 1987). Similar results were also reported by Shaltout (1987) and Aly (1988).

\section{Fruit firmness}

The obtained results show that fruit firmness $\left(\mathrm{Lb} / \mathrm{in}^{2}\right)$ was varied among the three cultivars and the highest significant fruit firmness resulted from "Early Grand" cultivar with (14.86 \& $\left.15.98 \mathrm{Lb} / \mathrm{in}^{2}\right)$ in 2007 and 2008 seasons, respectively while, the least values belonged to "Desert Red" and "Florida Prince" without significant difference between them in both seasons. Such results are in harmony with the findings obtained by El-Baz et al. (2007) who mentioned that "Early Grand" gave the highest values of fruit firmness (14.4 \& 16.6) but the least values belonged to "Florida Gold" in both seasons under ElWahat El-Baharia conditions. 
Generally, under the conditions of North Delta, "Early Grand" peach cultivar produced heaviest, largest, widest, longest and hardest fruits followed by "Desert Red" while, "Florida Prince" obtained lightest, smallest, narrowest, shortest and softest ones. On the other hand, there were no significant differences among cultivars in fruit shape in both seasons.

\section{Chemical fruit properties}

Total soluble solids (TSS)

Data presented in Table 12 revealed that, in both seasons total soluble solids percentage (TSS) was significantly the highest in fruits of "Early Grand" (11.54 \& 11.56) followed by "Florida Prince" (10.82 \& 10.61) and "Desert Red" (10.56 \& 10.47) which gave the lowest values without significant difference between them in both seasons. These findings are in harmony with those reported by El-Khoreiby et al. (2011). They found that the highest SSC percentage was given by Mit Ghamr (12.2 \& 12.0) followed by "Florida Prince" (10.4 \& 10.8) and "Desert Red" (10.8 \& 10.5) in descending order in the two seasons, respectively. Also, El-Baz et al. (2007) concluded that "Early Grand" had highest TSS content (10.87 \& 10.91\%), while, "Florida Prince" recorded least values in this respect.

\section{Total acidity}

The obtained data in Table 12 disclosed that "Early Grand" gave the lowest significant percentage of total acidity $(0.87 \& 0.85)$ but "Desert Red" $(1.10 \&$ $1.04)$ and "Florida Prince" (1.07 \& 1.00) showed higher values. The difference between them was not significant in both seasons. Similarly, El-Khoreiby et al. (2011) concluded that, Mit Ghamr had the lowest acidity $(0.6 \& 0.5 \%)$ followed by "Desert Red" (0.90 \& 0.95) and "Florida Prince" (1.04 \& 1.1\%) in the two seasons, respectively.

\section{TSS/acidity ratio}

Table 12 indicated that, TSS/acidity ratio take the same trend as influenced by cultivar and the highest significant values belonged to "Early Grand" (13.26 \& 13.60) compared to "Florida Prince" and "Desert Red" which recorded the least values without significant differences between them in both seasons. The variation in TSS/acidity ratio in peach cultivars was also noticed by Hussien (2009) who indicated that fruits of "Bokkeveld" had significantly higher values in (TSS/acidity ratio) compared to other cultivars.

Vitamin "C" content $(\mathrm{mg} / \mathrm{l} 00 \mathrm{~g})$

From the data of Table 12, it is clear that no significant differences were noticed in vitamin " $\mathrm{C}$ " content $(\mathrm{mg} / 100 \mathrm{~g})$ between the three studied peach cultivars in 2007 and 2008 seasons.

Anthocyanin pigment content $\left(\mathrm{mg} / \mathrm{cm}^{2}\right)$

As shown in Table 12, it is clear that the "Early Grand" recorded the highest significant values of anthocyanin content in fruit skin $\left(16.42 \& 16.51 \mathrm{ng} / \mathrm{cm}^{2}\right)$

Egypt. J. Hort. Vol. 42, No.1 (2015) 
compared to "Florida Prince" (15.81 \& 15.72) and "Desert Red" (15.623 \& 15.69) which obtained the least values and the difference among them was not significant in 2007 and 2008 seasons. These finding are in agreement with those of Aly (1988) who reported that "Florida Gold" and "Florida Prince" produced the highest significant values of anthocyanin pigments in fruit flesh than "Florida Bell" and "Florida Beauty" came next in this respect.

Generally, fruits of "Early Grand" had highest significant values of TSS, TSS/acidity and anthocyanin content and lowest significant values, total acidity as compared to "Florida Prince" and "Desert Red". The differences between "Florida Prince" and "Desert Red" were not significant in the first and second seasons. However, vitamin $\mathrm{C}$ content showed no significant difference among the three studied peach cultivars in both seasons.

TABLE 12. Chemical fruit properties of some peach cultivars in 2007 and 2008 seasons .

\begin{tabular}{|l|c|c|c|c|c|}
\hline \multicolumn{7}{|c|}{ Cultivar } & TSS \% & Acidity \% & $\begin{array}{c}\text { TSS/acidity } \\
\text { ratio }\end{array}$ & VC mg/100 g & $\begin{array}{c}\text { Anthocyanic } \\
\left(\mu \mathbf{g} / \mathbf{c m}^{\mathbf{3}}\right)\end{array}$ \\
\hline \multicolumn{7}{|c|}{$\mathbf{2 0 0 7}$ season } \\
\hline Florida prince & 10.82 & 1.07 & 10.11 & 9.63 & 15.81 \\
\hline Early Grand & 11.54 & 0.87 & 13.26 & 9.36 & 16.42 \\
\hline Desert Red & 10.56 & 1.10 & 9.60 & 9.46 & 15.62 \\
\hline LSD 0.05 & 0.67 & 0.48 & 1.11 & NS & 0.81 \\
LSD 0.01 & 0.97 & 0.70 & 1.61 & 2.18 \\
\hline \multicolumn{7}{|c|}{ 2008 season } \\
\hline Florida prince & 10.61 & 1.00 & 10.61 & 9.60 & 15.72 \\
\hline Early Grand & 11.56 & 0.85 & 13.60 & 9.51 & 16.51 \\
\hline Desert Red & 10.47 & 1.04 & 10.07 & 9.44 & 15.69 \\
\hline LSD 0.05 & 0.75 & 0.46 & 1.05 & NS & 0.86 \\
LSD 0.01 & 0.92 & 0.74 & 2.09 & 1.25 \\
\hline
\end{tabular}

\section{References}

Ahmed, M., Rhuman, H.U. Ahmed, I. Khokuhar, K.M. and Qurashi, (2002) Adaptability of peaches under sub-tropical region of Islamabad. Pakistan J. Agric. Res. 17(1), 42-45.

Aly, M.M. (1988) Evaluation of some new peach cultivars under Egyptian conditions. M.Sc. Thesis, Fac. of Agric., Caikro Univ., Egypt.

Dozier, W.A., Ebel, R.C. Powell, A.A. Caylor, A.W. Nesbitt, M.L. McDaniel, N.R. and W.R. Okie (1998) Performance of peach and nectarine cultivars on gulf cost area of Alabama. Fruit Printing 3M August, pp. 1-23.

El-Baz, E.T., Arafa, A.A. and Awad, W.M. (2007) Comparative study on growth and fruiting of some peach cultivars growing in two different locations. J. Agric. Sci. Mansura Univ., 52(8), 5863-5873. 
El-Etreby, S.M.A. (1996) Physiological studies on fruits of some old and new peach varieties. M.Sc. Thesis, Fac. of Agric. Cairo Univ., Egypt.

El-Khoreiby, A.M.K., Meloukl, A.M. Naglaa K.H. Serry and Abd El-Salam, N.A. (2011) Determination of maturity stage for some peach cultivars under Ismailia conditions. J. Plant Production. Mansour Univ., 2(1), 139-150.

Eliwa, G.I. (2005) Approach to new peach cultivars by the aid of Horticultural studies on Mit Ghamr peach chosen strains. J. Agric. Sci. Mansoura Univ., 30(8), 4649-4663.

Hussien, H.H.K. (2009) Evaluation of some peach cultivars grown in Egypt under desert conditions. M.Sc. Thesis, Fac. Agric., Cairo Univ., Egypt.

Mansour, N.M. and Stino, G.R. (1986a) Growth and flowering behaviour of some American peach cultivars under Egy ptian climate. Agric. Res. Rev., 64(3), 397-411.

Mansour, N.M. and Stino, G.R. (1986b) "Early Grand" and "Desert Gold", two promising peach cultivars adapted to Egy pt. Agric. Res. Rev., 64(3), 413-424.

Mansour, N.M. and Stino, G.R. (1987) Phy siological behaviour of a medium chelling requirement peach cultivar "Meadowlark". Agric. Res. Revi., 65(3), 333-340.

Ministry, of Agriculture and Land Reclamation (2010) Agricultural Economics. Annual Report, Cairo, Egypt.

Mohamed, A.I. (1995) Evaluation of some new introduced peach cultivars. M.Sc. Thesis, Fac. Agric., Ain Shams Univ., Egypt.

Shaltout, A.D. (1987) Florida Prince, a promising peach cultivar recently introduced to Egy pt. Fac. Agric., Cairo Univ., Bull., 38, (2).

Shaltout, A.D. (1995) Introduction and production of some low-medium chill peach cultivars in the sub-tropical climate of Egypt. Assiut. J. Agric. Sci., 26(1), 195-206.

Sherman, W.B. and Lyrene, P.M. (1989) "Florida Star" peach. Fruit Crops Department, University of Florida, Gainesville, FL32611, HortScience, 24(2), 395396.

Snedecor, G.W. and W.G. Cochran (1990) "Statistical Methods", $7^{\text {th }}$ ed. The Iowa State Univ. Press, Ames. Iowa, USA, p. 593.

Sottile, F.M. Monte, Omodei, F. and Barbera, G. (2003) Fertility index, flowering aspects and pomological traits on almond getotypes from different areas. Options Mediterranée, Série A, Numéro 63, 167-170.

Stino, G.R., Mansour, N.M. and Hamouda, A. (1982) Characters of four American peach cultivars grown in Egypt. Fac. Agric., Ain Shams Univ., Res. Bull., 2082.

(Received 21/8/2014 accepted 25/9/2014)

Egypt. J. Hort. Vol. 42, No.1 (2015) 
تقييم ثُلاث أصناف من أشجار الخوخ المنزرعة تحت ظروف شمال

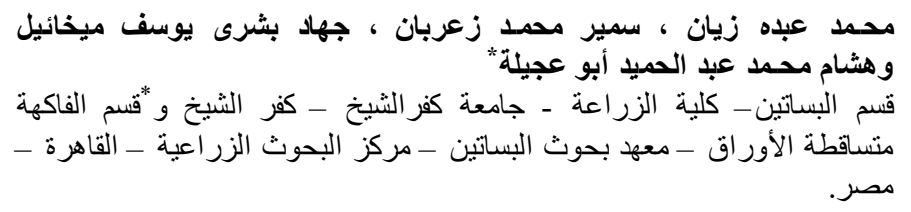

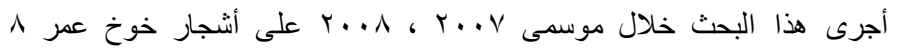

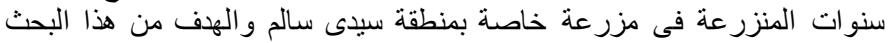

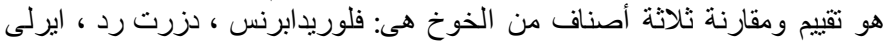

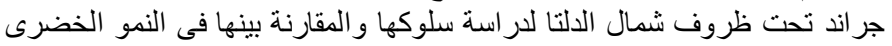

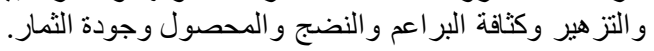

و أمكن تلخيص النتائج النتحصل عليها فى النقاط التالية:

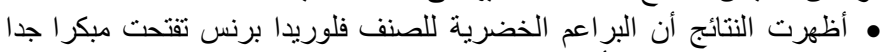

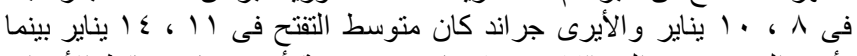

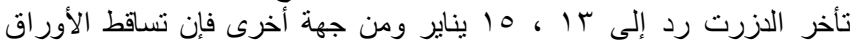

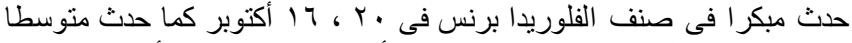

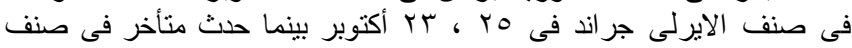

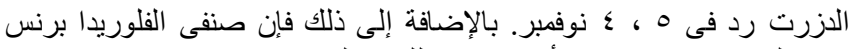

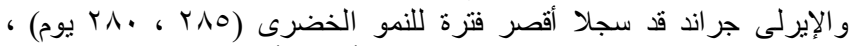

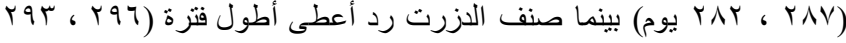

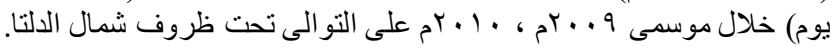

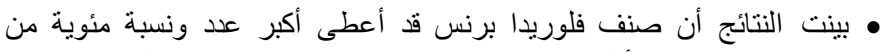

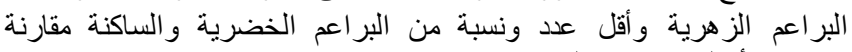

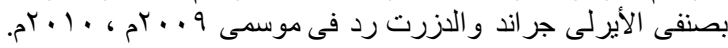

• أوضحت النتائج أن صنف فلوريدا برنس أعطى أطول نمو ات وسلاميات و أكبر

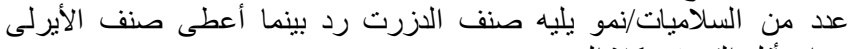
جر اند أقل القيم فى كلا الموسمين.

• أظهرت النتائج أن ميعاد تقتح البراعم الزهرية لكل أصناف الخوخ المختبرة

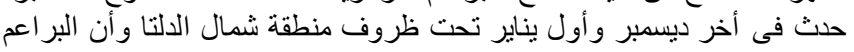

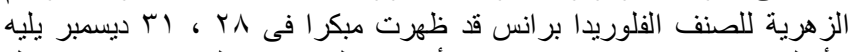

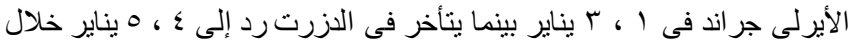

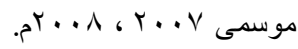

• بينت النتائج اختلاف مكان البراعم الزهرية على النمو من صنف إلى أخر.

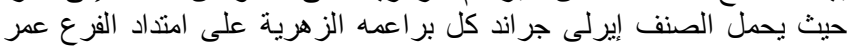

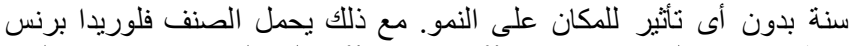

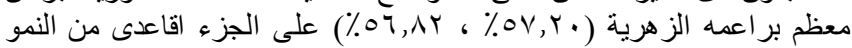

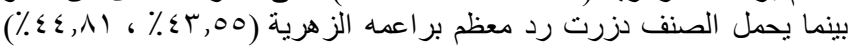
على الجزء الوسطى من النمو خلال موسمي الدراسة.

Egypt. J. Hort. Vol. 42, No.1 (2015) 
أوضحت النتائج أن صنف الفلوريدا برنس أعطى أعلى قيمة معنوية لاليل

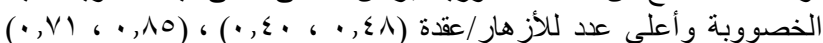

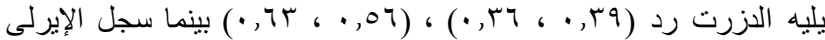

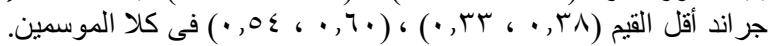

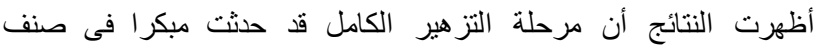

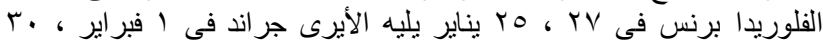

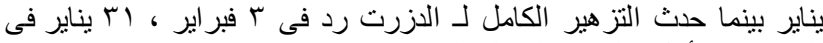

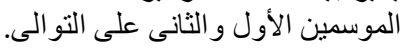

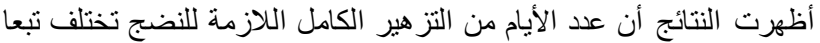

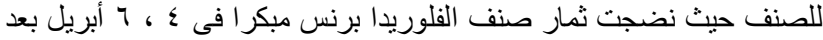

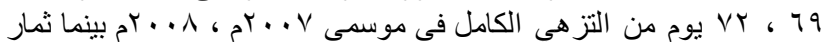

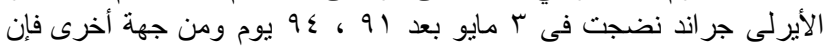

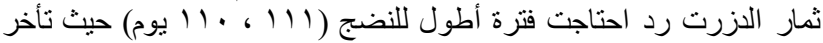

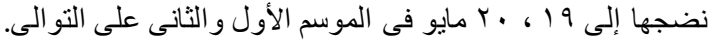

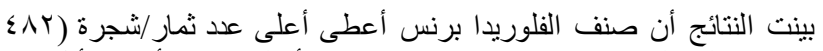

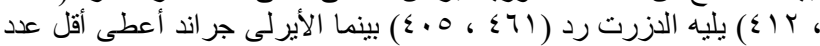

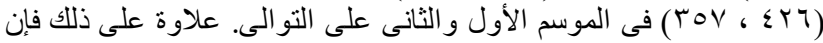

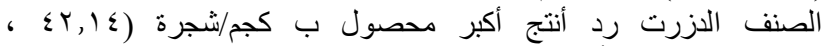

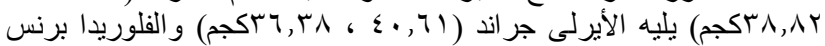
(

أوضحت النتائج أنه تحت ظروف شمال الدلتا ينتج الصنف أيرلى جر اند أثقل

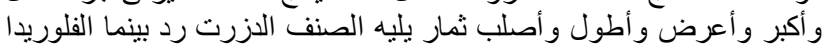
برنس يعطى أخف و أصغر وأطر وأضيق و أقصر و أطرى ثمار.

ثمار الأيرلى جراند أعطت أعلى قيم معنوية للمواد الصلبة الذائبة الكلية

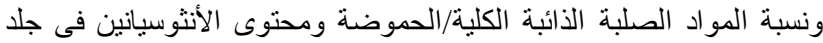

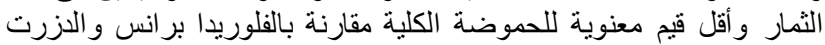

